\title{
PERKEMBANGAN RADIO SEBAGAI PERS ELEKTRONIK DI MADIUN
}

\author{
TAHUN 1998-2013
}

\section{Yara Ardiningtyas \& Yudi Hartono*}

\begin{abstract}
Abstrak
Penelitian ini bertujuan untuk mengetahui perkembangan radio yang ada di Madiun pada tahun 1998-2013. Pendekatan yang digunakan dalam penelitian ini adalah pendekatan kualitatif. Jenis pendekatannya adalah pendekatan studi kasus. Pengumpulan data menggunakan metode wawancara (interview), dokumentasi dan observasi lapangan. Dalam menganalisis data menggunakan metode wawancara (interview) dan penelitian lapangan (research). Analisis data yang digunakan adalah analisis data model interaktif Miles dan Huberman yang didalamnya terdapat 3 tahapan yaitu melalui proses reduksi data, sajian data dan verifikasi atau proses penarikan kesimpulan. Berdasarkan hasil penelitian membuktikan bahwa perkembangan radio di Madiun dari tahun 1998-2013 mengalami perkembangan. Indikasi mengalami perkembangan adalah radio-radio di Madiun dalam segi teknologi penyiaran sudah tudak lagi menggunakan analog melainkan sudah menggunakan komputerisasi. Program acara yang dimiliki setiap radio di Madiun juga mengalami perkembangan yaitu dengan munculnya program-program baru yang lebih kreatif dan inovatif sehingga digandrungi oleh pendengar radio. Setiap radio kini juga mempunyai pemancar yang permanen yang terletak di studio siarannya, sehingga jangkauan siaranya lebih luas dan lebih jelas dan dapat dinikmati oleh semua masyarakat Karisidenan Madiun. Informasi dari segala bidang (pendidikan, ekonomi, sosial budaya, politik dan kewirausahaan) dapat diperoleh oleh masyarakat dari berbagai golongan. Berkembang dan bertahanya radio di era modern ini juga merupakan bukti bahwa masyarakat juga masih percaya dengan radio. Sebagai sarana publikasi dan memperoleh informasi dengan cepat dan relatif murah dengan bahasa yang mudah dipahami, sehingga radio dapat dikonsumsi dari berbagai kalangan masyarakat. Radio yang ada di Madiun juga menjalankan fungsinya sebagai sosial kontrol, sumber informasi, dan sebagai hiburan.
\end{abstract}

\section{Kata Kunci : Radio, Pers Elektronik dan Madiun}

\section{Pendahuluan}

Dewasa ini perkembangan pers sangat pesat dan tidak terbendung. Di berbagai negara terdapat pers yang memenuhi kebutuhan masyarakat akan informasi yang dapat diakses secara cepat dan tanpa mengeluarkan biaya yang banyak. Semua menyadari betapa pentingnya peranan dan partisipasi pers dalam pembangunan suatu negara. Menurut
Undang-Undang Republik Indonesia Nomor 40 Tahun 1999, Tentang Pers, istilah 'pers' berarti lembaga sosial dan wahana komunikasi massa yang melaksanakan kegiatan jurnalistik meliputi, mencari, memperoleh, memiliki, menyimpan, mengolah, dan menyampaikan informasi baik dalam bentuk tulisan, suara, gambar, suara dan gambar, serta data dan grafik maupun dalam bentuk lainnya dengan

\footnotetext{
* Yara Ardiningtyas adalah Alumni Program Studi Pendidikan Sejarah IKIP PGRI MADIUN

* Yudi Hartono adalah Dosen Program Studi Pendidikan Sejarah IKIP PGRI MADIUN
} 
menggunakan media cetak, media elektronik, dan segala jenis saluran tersedia.

Perkembangan pers di Indonesia sebagian besar dipengaruhi oleh adanya usaha percetakan dan penerbitan Belanda maupun Tionghua, sebagian besar lagi dikarenakan munculnya elite Indonesia yang memerlukan media komunikasi. Pers merupakan tanda-tanda pertama perubahan masyarakat Indonesia, yang berkaitan dengan berkembangnya ekonomi, terutama dengan makin banyaknya usaha perekebunan dan semakin meluasnya perdagangan, perkembangan politik, dan didirikan sekolah-sekolah model Belanda (Hilman Adil, 2002 : 9).

Pers dibagi menjadi dua yaitu pers cetak dan pers elektronik, salah satu pers elektronik di Indonesia adalah Radio. Radio merupakan salah satu bentuk media massa yang banyak digunakan masyarakat untuk mengakses informasi. Radio pertama kali ditemukan oleh Marconi pada tahun 1896. Pada awalnya radio berfungsi sebagai alat untuk menyampaikan informasi dan berita ataupun untuk kepentingan kenegaraan secara umum. Radio publik atau komersil baru muncul pada tahun 1920-an (Masduki, 2006:2). Sejak tahun itu perkembangan radio berkembang pesat. Radio merupakan sumber informasi yang kompleks mulai dari fungsi tradisional, radio sebagai penyampai berita dan informasi, perkembangan ekonomi, pendongkrak popularitas, hingga propaganda politik dan ideologi sistem komunikasi radio adalah sistem komunikasi yang tidak menggunakan kawat dalam proses perambatannya, melainkan menggunakan udara atau ruang angkasa sebagai bahan penghantar.

Radio lebih sering dipahami sebagai sarana hiburan. Sering tidak disadari bahwa dibalik itu selama ini terselip fungsi yang lain, yaitu sebagai alat propaganda politik. Demikianlah menurut Masduki sepanjang Orde Baru, oleh pengelola dan pendengarnya, radio menjadi sarana hiburan utama, di luar film dan televisi. Sejak pemerintah Belanda selain fungsinya sebagai media hiburan, radio memang dijadikan sebagai alat penyebaran dan kontrol politik pemerintah melalui NIROM (Nederlands Indische Radio Omroep Maatschappij).

Demikian pula pada zaman Jepang, radio dipusatkan dibawah NHK (Nippon Hoso Kyoko) sebagai media untuk propaganda Perang Asia Raya. Tahun 1945 NHK direbut oleh para aktivis dan diubah menjadi RRI (Radio Republik Indonesia) dan pada saat yang bersamaan berdiri radio-radio swasta independen yang memberikan dukungan pada revolusi (2006:v). Radio bisa berfungsi sebagai alat kontrol dan perjuangan menggugat kesewenangan. Akan tetapi, sepanjang Orde Baru, radio kembali dikebiri, didudukkan hanya sebagai sarana hiburan, alat propaganda dan kontrol negara. Media radio juga mempunyai kekuatan besar 
sebagai sarana pendidikan serta agen perubahan sosial. Dibanyak Negara berkembang UNESCO melakukan eksperimen mengenai pemanfaatan media radio untuk peningkatan pengetahuan masyarakat. Radio merupakan sarana yang bagus untuk program pendidikan masyarakat (Antonius Darnanto, 1998:viii).

Radio menempatkan diri sebagai medium penyiaran berita setara dengan media strategis lainya, seperti media cetak dan televisi. Perkembangan jurnalistik radio di Indonesia dari segi umur masih bayi, bahkan "baru lahir" ketika menteri penerangan M. Yunus Yosfiah mengeluarkan surat edaran No. 134/SK/MENPEN/1998 tertanggal 5 Juni 1998, yang berisi pengurangan "kewajiban" relay warta berita RRI dari 14 kali menjadi 3 kali sehari, pemberian izin bagi radio swasta untuk membuat dan menyiarkan berita sendiri, diperbolehkan relay siaran radio asing; serta penggunakan istilah, intonasi maupun gaya bahasa jurnalistik yang sesuai segmen pendengar radio bersangkutan (Masduki, 2006:xiii).

Willian L. River berpendapat bahwa walaupun radio kian terdesak oleh televisi dan media cetak namun masih memiliki penggemar (2008:21). Radio tidak hanya diminati oleh kalangan atas saja tapi juga kalangan menengah ke bawah. Salah satu stasiun penyiaran radio milik pemerintah yang ada di berbagai daerah adalah RRI. Sampai saat ini RRI memiliki 52 stasiun penyiaran yang tersebar di berbagai daerah (duniaradio.com,diakses tanggal 20 febuari tahun 2014). Salah satu stasiun penyiaran RRI juga terdapat di Madiun.

Kota Madiun merupakan salah satu kota di Provinsi Jawa Timur yang berada pada $111^{\circ} \mathrm{s} / \mathrm{d} 112^{\circ}$ bujur timur dan $7^{\circ} \mathrm{s} / \mathrm{d}$ $8^{\circ}$ lintang selatan, sedangkan luas wilayah Kota Madiun adalah 33,23 $\mathrm{km}^{2}$ yang terbagi menjadi 3 kecamatan, 27 kelurahan dimana masing-masing kecamatan terbagi menjadi 9 kelurahan (BPS Kota Madiun, 2011:1). Madiun terletak didaerah persimpangan jalur perdangan, industri dan komunikasi dari wilayah barat menuju wilayah timur. Banyak perkembangan yang berkembang pesat di kota besar juga merambah dan berkembang di kota yang berada pada jalur tersebut. Madiun juga mendapat imbas dari perkembangan teknologi komunikasi khususnya Radio.

Dengan adanya kebebasan pers pada era reformasi, dimana pemerintah memberi kebebasan untuk tumbuh dan berkembang, baik pers cetak maupun elektronik. Kebebasan ini kemudian melahirkan raksasa-raksasa media, disebut raksasa karena semua lini media digeluti: surat kabar, majalah, televisi, radio dan website. Adanya hal tersebut penyiaran radio di Madiun dimulai dengan berkembanganya radio amatir atau radio swasta yang menggunakan perangkat pemancar radio sederhana yang mudah dirakit. Selain RRI radio yang dimiliki pemerintah yang ada 
didaerah-daerah, seperti di Madiun. Hal ini dapat mempengaruhi masyarakat Kota Madiun untuk mendirikan usaha di bidang penyiaran radio. Kondisi ini bisa dilihat dengan banyaknya penyiaran radio swasta yang bermunculan didaerah Madiun, seperti radio Gabriel, radio Prima, radio Pesona, radio Wijaya Kusuma, radio DCS, radio Moderato, radio Madya dan radio Harmoni. Mulai dari penyiaran radio yang disiarkan selama 18 jam sampai 24 jam. Adanya persebaran penyiaran radio yang berlangsung membuat informasi mudah di akses dan menyebar pada semua kalangan masyarakat di wilayah Madiun dan sekitarnya.

Sementara itu, di luar perkiraan banyak orang dengan berkembangnya televisi-televisi swasta lebih satu dekade terahir, radio tidak tergeser perannannya. Bahkan dalam banyak hal radio semakin vital, ini mungkin dari segi praktisnya. Radio bisa dengan mudah dibawa dan didengarkan, baik sambil membaca, bekerja, ataupun yang lainnya. Berbeda pula dengan media elektronik visual, interaksi dengan radio bisa lebih dalam dan imajinatif.

Sekarang dan di masa mendatang, beriring dengan semangat demokrasi, radio akan memainkan kembali satu sisi perannya yaitu sebagai penyalur berita, hiburan dan kontrol sosial terhadap pemerintah. Radio siap bersaing dengan media pers lainnya, cetak maupun elektronik. Bertolak dari uraian di atas maka peneliti terdorong mengkaji dan meneliti Perkembangan Radio Sebagai Pers Elektronik di Kota Madiun Tahun 1998 - 2013.

\section{Kajian Pustaka}

\section{Pengertian Pers}

Istilah "pers" berasal dari bahasa Belanda, yang dalam bahasa Inggris berarti press. Secara harfiah pers berarti cetak dan secara maknawiah berarti penyiaran secara tercetak atau publikasi secara dicetak (printed publications). Dalam perkembangannya pers mempunyai dua pengertian, yakni pers dalam pengertian luas dan pers dalam pengertian sempit. Pers dalam pengetian luas meliputi segala penerbitan, bahkan termasuk media massa elektronik, radio siaran dan televisi siaran, sedangkan pers dalam pengrtian sempit hanya terbatas pada media massa cetak, yakni surat kabar, majalah, dan buletin kantor berita.

Kenyataan bahwa radio dan televisi termasuk dalam lingkup pers jika diadakan jumpa pers (press conference), maka yang meliput berita dalam pertemuan itu bukan hanya wartawan surat kabar, majalah dan kantor berita, melainkan juga wartawan-wartawan televisi dan radio. Ini karena dalam radio dan televisi juga terdapat kegiatan jurnalistik yang hasilnya berbentuk berita seperti yang dimuat dalam surat kabar (Onong Uchjana effendi, 2009:145). Pers biasanya lebih tertarik 
pada isu-isu penting yang mempengaruhi suatu industri atau hasil penelitian yang menyoroti sikap atau tingkah laku publik dibandingkan promosi langsung suatu produk atau suatu kampanye. Materi seperti itu biasanya banyak membantu mengembangkan rasa hormat serta kerja sama yang lebih tinggi dengan wartawan sasaran (Sahrul, 2004:57).

Berdasarkan uraian di atas dapat disimpulkan bahwa pers dapat dibedakan menjadi dua, yaitu pers cetak dan pers elektronik. Pers cetak meliputi koran, majalah, tabloid dan brosur, sedangkan pers elektronik meliputi televisi, internet dan siaran radio. Kedua bentuk pers tersebut adalah badan penerbitan media massa yang dijadikan alat perjuangan nasional yang mempunyai karya sebagai salah satu media komunikasi massa menyiarkan berita secara cetak atupun suara dan gambar yang diterbitkan secara berkala baik harian, mingguan dan bulanan yang menyajikan informasi berupa berita, hiburan, iklan, media kampanye dan himbauan pemerintah sebagai kontrol sosial.

\section{Pengertian Radio}

Masyarakat dengan tingkat
ekonomi rendah memiliki
ketergantungan dan kebutuhan media
massa yang lebih tinggi dari pada
masyarakat dengan tingkat ekonomi
lebih tinggi karena pilihan mereka yang

terbatas. Masyarakat dengan tingkat ekonomi lebih tinggi memiliki lebih banyak pilihan dan akses banyak media massa, termasuk bertanya langsung pada sumber atau ahli dibandingkan mengandalkan informasi yang mereka dapat dari media massa tertentu. Untuk memperoleh pengertian dari radio yang baku sehingga dapat dijadikan sebagai standarisasi dalam menelaah persoalan ilmiah harus membandingkan dari berbagai pendapat para ahli.

Radio juga bisa disebut sebagai media massa, karena memenuhi ciri-ciri komunikasi massa, yakni komunikasi menggunakan media massa yang berlangsung secara satu arah, komunikasinya melembaga, pesan bersifat umum, medianya menimbulkan keserempakan dan komunikasinya secara heterogen (Onong Uchjana Effendy,2009:145).

Menurut The Encyclopedia of Americana International radio merupakan alat komunikasi yang menggunakan gelombang elektromagnetik yang disebarkan melalui ruang pada kecepatan cahaya. Gelombang elektromagnetik yang digunakan dalam komunikasi radio persis dengan cahaya dan gelombang panas tetapi frekuensinya lebih rendah (Dalam Triartanto,2010:30). Radio juga disebut teknologi yang digunakan untuk mengirimkan sinyal dengan cara 
modulasi dan radiasi gelombang elektromagnetik. Gelombang ini melintas dan merambat lewat udara dan bisa juga merambat lewat luar angkasa yang hampa udara, karena gelombang ini tidak memerlukan medium pengangkut seperti medium udara (Asep Samsul, 2009:12).

Senada dengan pendapat Santi Indra bahwa radio yaitu buah perkembangan teknologi yang memmungkinkan suara ditrasmisikan secara serempak melalui gelombang radio di udara (2008:5). Radio adalah suara. Suara merupakan modal utama terpaan radio kehalayak dan stimulasi yang dikoneksikan kepadanya khalayak. Suara dalam sebuah radio merupakan suatu tekanan emosional perseptual, dan fisikal yang timbul dan berasal dari suara yang termediasi oleh teknologi yang kemudian menimbulkan formasi imajinasi fisual tertentu dibenak pendengar (Masduki, 2004:16).

Anton M. Moelino berpendapat bahwa radio didefinisikan sebagai siaran pengiriman suara atau bunyi melalui suara. Pendapat senada juga diungkapkan oleh Triantanto yang menyatakan radio adalah alat komunikasi massa yang menggunakan lambang komunikasi yang berbunyi (2010:30). Lebih lanjut diungkapkan oleh Chantler dan Harris bahwa radio merupakan media massa terbaik untuk berimajinasi (dalam Herley Prayudha,
2006:12). Pendengar selalu mencoba berimajinasi terhadap apa yang didengar dan apa yang dijelaskan. Gambaran dalam radio tidak terbatas oleh ukuran sebuah layar, tetapi lebih dalam dan menurut apa yang diinginkan oleh pendengar radio, maka radio dapat memberikan kesan tersendiri dalam pikiran pendengar.

Dari berbagai pendapat di atas dapat disimpulkan bahwa radio adalah suatu media massa elektronik yang dijadikan sebagai alat komunikasi melalui cara modulasu dan radiasi gelombang elektromagnetik. Gelombang ini melintas dan merambat lewat udara dan bisa juga merambat lewat ruang angkasa yang hampa udara, karena gelombang ini tidak memerlukan medium pengangkut. Radio menyiarkan berbagai komunikasi massa berupa berita baik regional maupun nasional sarana hiburan, wawasan budaya dan bisa juga dijadikan alat himbauan atau kontrol sosial oleh pemerintah.

\section{Karakteristik Radio}

Radio sebagai media massa elektronik mempunyai prinsip utama siaran adalah visualisasi, yakni berimajinasi, membayangkan berbicara kepada seorang pendengar yang duduk di depan kita. Sekalipun radio disebut media buta karena hanya berupa suara, namun suara merupakan instrumen penting dalam meninbulkan imajinasi 
pendengar. Asep Samsul berpendapat radio memiliki lima karakteristik khas yaitu (2009:19) :

a. Auditori, sound only, auditf

Radio adalah suara, untuk didengar dikonsumsi telinga atau pendengaran. Apapun yang disampaikan melalui radio harus berbentuk suara, hanya suara, lain tidak.

b. Transmisi

Radio proses penyebarluasannya atau disampaikan kepada pendengar melalui pemancar (trasmisi).

c. Mengandung gangguan

Gangguan radio yang terjadi sering seperti timbul tenggelam atau fading dan gangguan teknis "channel noise faktor"

d. Theatre of mind

Radio menciptakan gambar dalam imajinasi pendengar, memainkan imajinasi pendengar, dengan kekuatan kata dan suara. Secara harfiah berarti ruang bioskop dalam pikiran. Radio mampu menggugah imajinasi pendengarnya dengan suara, musik, vokal atau bunyibunyian.

e. Identik dengan musik

Umumnya orang mendengarkan radio untuk mendengarkan music atau lagu. Radio digunakan sebagai media utama untuk mendengarkan musik.

\section{Jenis-jenis Radio}

Menurut Robet McLeish dalam Masduki (2004:26-27) jenis-jenis radio yang popular adalah :

1. Public Sevice Station, radio yang memiliki dan melayani kepentingan umum secara nasional.

2. Commercial Statio radio milik pribadi yang digunakan untuk mencari keuntungan komersial.

3. Government Station, yaitu radio pemerintah yang digunakan untuk kepentingan umum

4. Government Owned Station, radio milik pemerintah yang sepenuhnya dipergunakan sebagai alat propaganda.

5. Institutional Ownership Station, radio yang dimiliki ormas, kampus dan LSM.

6. Community Ownership, radio milik komunitas kecil dilingkup kelurahan.

Di Indonesia sebelum tahun 1998 hanya dikenal dengn dua tipe radio, yaitu radio pemerintah (Government Owned Station) dan radio komersial. Meskipun radio komunitas sudah mulai ada, secara politik dilarang dan dicap sebagai radio gelap. Konsep radio publik baru ada di UU No. $32 / 2002$ yang menyatakan radio publik dikenal dengan konsep radio pemerintah (RRI), sedangkan radio komersial hadir lebih awal di Indonesia 
dibandingkan radio Komunitas.

Perbedaan tiga bentuk lembaga radio menurut Masduki dapat dilihat di tabel berikut ini (2004:26) :

Tabel 2.1 Perbedaan Bentuk Lembaga

Radio

\begin{tabular}{|c|c|c|c|}
\hline Bentuk & $\begin{array}{l}\text { Radio } \\
\text { Politik }\end{array}$ & $\begin{array}{l}\text { Radio } \\
\text { Komu } \\
\text { nitas }\end{array}$ & $\begin{array}{c}\text { Radio } \\
\text { Komer } \\
\text { sial }\end{array}$ \\
\hline $\begin{array}{l}\text { Sifat } \\
\text { pengel } \\
\text { olaan }\end{array}$ & $\begin{array}{l}\text { Nonprof } \\
\text { it (tidak } \\
\text { mencari } \\
\text { untung) }\end{array}$ & $\begin{array}{l}\text { Nonpr } \\
\text { ofit }\end{array}$ & $\begin{array}{l}\text { Profit } \\
\text { (menca } \\
\text { ri } \\
\text { untung } \\
\text { ) }\end{array}$ \\
\hline $\begin{array}{l}\text { Jangka } \\
\text { uan } \\
\text { geograf } \\
\text { is }\end{array}$ & $\begin{array}{l}\text { Nasiona } \\
\text { l, } \\
\text { internas } \\
\text { ional }\end{array}$ & $\begin{array}{l}\text { Sangat } \\
\text { lokal }\end{array}$ & $\begin{array}{l}\text { Lokal, } \\
\text { jaringa } \\
\text { n }\end{array}$ \\
\hline $\begin{array}{l}\text { Pemilik } \\
\text { dan } \\
\text { pengel } \\
\text { ola }\end{array}$ & $\begin{array}{l}\text { Negara } \\
\text { di } \\
\text { bawah } \\
\text { Kement } \\
\text { rian } \\
\text { Peneran } \\
\text { gan }\end{array}$ & $\begin{array}{l}\text { Kelom } \\
\text { pok } \\
\text { masyar } \\
\text { akat }\end{array}$ & $\begin{array}{l}\text { Individ } \\
\mathrm{u} \text { atau } \\
\text { kelomp } \\
\text { ok }\end{array}$ \\
\hline $\begin{array}{l}\text { Pembu } \\
\text { atan } \\
\text { keputu } \\
\text { san } \\
\text { siaran }\end{array}$ & $\begin{array}{l}\text { Buttom } \\
\text { up } \\
\text { (aspiras } \\
\text { i dari } \\
\text { bawah) }\end{array}$ & $\begin{array}{l}\text { Buttom } \\
\text { up } \\
\text { (aspira } \\
\text { si dari } \\
\text { bawah) }\end{array}$ & $\begin{array}{l}\text { Top } \\
\text { down } \\
\text { (ditent } \\
\text { ukan } \\
\text { oleh } \\
\text { pengel } \\
\text { ola) }\end{array}$ \\
\hline
\end{tabular}

\section{Kelebihan dan Kekurangan Radio}

Dalam pers cetak maupun elektronik memiliki kelebihan dan kekurangan. Menurut Efendi (dalam Triartanto, 2010:36-37) radio siaran memiliki kelebihan yaitu, (1) radio bersifat langsung artinya program yang disampaikan tidak mengalami proses yang kompleks, berita, informasi ataupun pesan disampaikan oleh penyiar dapat diterima secara langsung pada waktu itu juga; (2) radio siaran menembus jarak dan rintangan yaitu radio siaran dapat menembus jarak yang jauh walau dirintangi oleh gunung, lembah, padang pasir maupun lautan sehingga jarak tidak menjadi soal dan rintangan; (3) radio siaran mengandung daya tarik yaitu radio siaran memiliki siaran yang serba hidup berkat unsur musik, kata atau suara manusia dan efek suara.

Kekurangan dari penyiaran radio, (1) durasi program terbatas yaitu radio siaran dalam setiap programnya dibatasi oleh durasi waktu setiap program memiliki rentan waktu masing-masing yang maksimal durasi waktu program selama 240 menit atau 4 jam yang terbagi dalam sekmen acara; (2) sekilas dengar yang dimaksutkan sifat radio siaran adalah auditori untuk didengar maka siaran yang sampai ke telinga pendengar hanya sekilas dan sepintas saja sehingga isi pesan atau informasi gampang lenyap dari ingatan pendengar 
dan siaran radio tidak bisa disiarkan ulang; (3) mengandung gangguan yaitu setiap penyampaian komunikasi dengan menggunakan bahasa lisan atau ucap melalui media mengalami gangguan yang sifatnya teknis (channel, mechanic noise).

$$
\text { Pendapat senada juga }
$$
dikemukakan oleh Asep Samsul Romli (2009:19-20) mengenai kelebihan dan kekurangan radio, di antaranya kelabihan radio yaitu (1) cepat dan langsung yaitu menyampaikan informasi kepada publik tanpa proses yang rumit dan lama; (2) akrab, radio alat yang akrab dengan pemiliknya yakni biasanya radio didengarkan sendirian oleh pendengar baik di mobil, di dapur dan sebagainya; (3) bersifat personal karena mampu menyentuh pribadi pendengar. Suara penyiar hadir di rumah atau di dekat pendengar, pembicaraan langsung menyentuh aspek pribadi;

(4) hangat dan sederhana, paduan kata-kata, musik dan efek suara dalam siaran radio mampu mempengaruhi emosi pendengar tidak rumit, tidak banyak pernik bagi penglola maupun pendengar; (5) tanpa batas, wilayah siaran radio sangat luas menembus batas geografis, demografis, agama, ras dan kelas sosial; (6) murah dibandingkan dengan berlangganan media cetak atau harga televisi, radio relative jauh lebih murah. Mudah dijangkau oleh kalangan masyarakat manapun, pendengarpun tidak dipungut biaya sepeser pun untuk mendengarkan radio; (7) fleksibel, siaran radio dapat dinikmati sambil mengerjakan aktivitas lain seperti memasak, mengemudi dan membaca koran atau majalah.

Di sisi lain siaran radio juga memiliki kekurangan, diantaranya (1) selintas, At Once dapat diakses dengan cepat dan seketika, juga cepat pula hilang dan gampang dilupakan. Pendengaran tidak bisa mengulang apa yang didengarnya, tidak bisa seperti pembaca koran yang bisa mengulang bacaannya dari awal; (2) global, sajian informasi radio bersifat global tidak detai karena angka dibulatkan. Misalnya penyiar akan menyebut "seribu orang lebih"untuk angka 1.053 orang; (3) batasan waktu siaran radio relatife terbatas hanya 24 jam sehari. Berbeda dengan surat kabar yang bisa menambah jumlah halaman dengan bebas;

(4) linier program disajikan dan dinikmati pendengar berdasarkan urutan tidak bisa meloncat-loncat. Beda dengan surat kabar, pembaca bisa langsung ke halaman tengah, akhir, atau langsung ke rubrik yang disukai; (5) mengandung gangguan jaringan sering timbul dan tenggelam (fading) dan gangguan teknis "channel noise factor"; (6) Lokal media radio bersifat lokal hanya didaerah yang ada frekuensinya (Asep Samsul, 2009:21). 


\section{Metode Penelitian}

Penelitian ini bertujuan untuk mengetahui perkembangan radio yang ada di Madiun pada tahun 1998-2013. Pendekatan yang digunakan dalam penelitian ini adalah pendekatan kualitatif. Jenis pendekatannya adalah pendekatan studi kasus. Penelitian studi kasus ini dapat membantu peneliti dalam mengungkap masalah yang terjadi dalam perkembangan radio yang ada di Madiun tahun 1998-2013.

Sumber Data yang digunakan sumber data primer dan sekunder. Data Primer, dimana penelitian ini memperoleh informasi dari pimpinan radio, divisi penyiaran dan divisi SDM atau umum dari masing-masing perusahaan radio yang ada di Madiun. Sedangkan data sekunder, dimana data ini digunakan untuk menguatkan teori yang digunakan dalam landasan peneliti dalam melakukan penelitian yang diperoleh dari referensi kepustakaan yang berfungsi menguatkan data yang diperoleh dari lapangan.

Pengumpulan data menggunakan metode wawancara (interview), dokumentasi dan observasi lapangan. Dalam menganalisis data menggunakan metode wawancara (interview) dan penelitian lapangan (research). Analisis data yang digunakan adalah analisis data model interaktif Miles dan Huberman yang didalamnya terdapat 3 tahapan yaitu melalui proses reduksi data, sajian data dan verifikasi atau proses penarikan kesimpulan.

Analisis data penelitian ini menggunakan model analisis interaktif. Model analisis interaktif memungkinkan untuk melakukan pengumpulan data di lapangan dengan langsung menggunakan tiga komponen penelitian, yaitu reduksi data, penyajian data dan penarikan simpulan atau verifikasi (Sutopo, 2006:119).

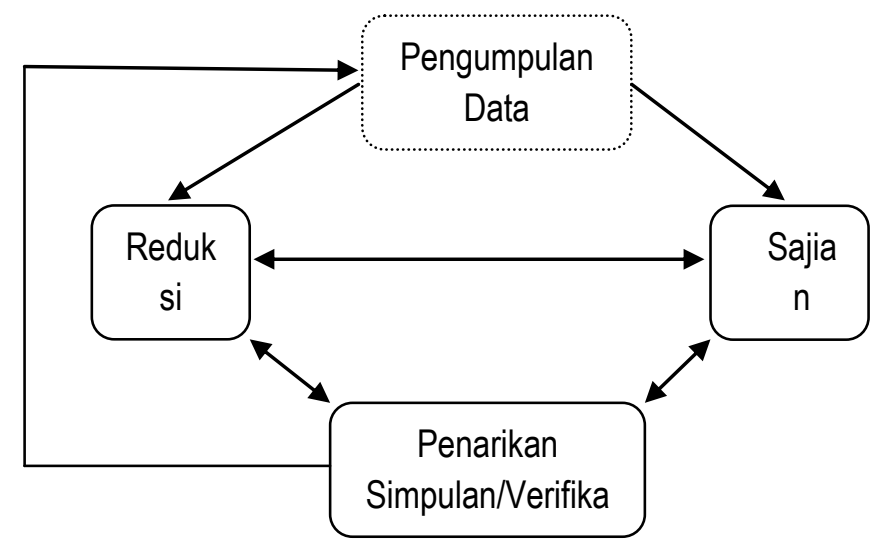

Analisis Interaktif Miles dan Huberman

Sumber : dalam H.B Sutopo, 2006:120

\section{Hasil Penelitian}

\section{A. Periode Pertama Perkembangan}

\section{Radio Sebagai Pers Elektronik Tahun} 1998-2003

RRI sebagai pionir perkembangan radio di wilayah Kota Madiun, pada awal berdirinya merupakan radio yang didirikan oleh pemerintah dibawah pengawasan departemen penerangan. RRI tergolong dalam jenis radio public service station dan government station yang mana RRI adalah radio pemerintah yang memiliki dan melayani kepentingan umum secara nasional. Pemerintah Kota 
Madiun menggunakan RRI sebagai media informasi untuk menghimbau dan memberikan penyuluhan yang berkaitan dengan pendidikan, ekonomi dan kesehatan serta memberikan hiburan.

Sebagai sarana media komunikasi masa, dibidang pendidikan pemerintah sering melakukan himbauan-himbauan tentang pentingnya pengentasan buta huruf, pendidikan wajib belajar 9 tahun dan pelaksanaan program kejar paket. Program keluarga berencana (KB) dan perkembangan harga kebutuhan pokok juga diinformasikan oleh pemerintah yang digunakan untuk dari kontrol dari sektor ekonomi dan keseahatan.

RRI juga merintis sebagai radio komersial hal ini dikarenakan agar RRI mendapatkan iklan untuk membantu pengembangan dan kemajuan RRI. Perubahan fungsi ini juga disebabkan karena adanya penghapusan Departemen Penerangan oleh pemerintahan Presiden Abdurrahman Wahid yang mengacu pada Peraturan Pemerintah Nomor: 37 Tahun 2000. Perusahaan-perusahaan yang memasang iklan dan menjadi langganan RRI yaitu Hotel Sarangan, Toko Mas Delima, CV Tunas, PT Petrokimia Gresik, Industri Logam (CV Mahkota), Gudang Garam, Toko Mega Jati, CV Nusa Indah Ponorogo dan masih banyak lagi.

Adanya penambahan masukan, membuat RRI melakukan pembenahan dalam teknologi penyiaran. Perkembangan teknologi siaran dari awal berdiri sampai sekarang selalu mengalami perubahan dan perbaikan. Bermula dari perpindahan kantor siaran yang permanen dari Jl. Pahlawan dan menetap di Jl. Mayjen Panjaitan pada tahun 1981.

Adanya tempat yang luas membuat RRI mulai mendirikan pemancar yang permanen dengan tujuan siaran supaya dapat menjangkau kawasan karisidenan Madiun. Perubahan dan perbaikan pemancar dari pemancar shot wife (SW) menjadi pemancar audio modulasi (AM) sampai didirikannya pemancar frekfensi modulasi (FM). Perkembangan teknologi penyiaran RRI masih menggunakan peralatan yang sangat sederhana dan masih manual. Pemutaran musik menggunakan tape recorder dan VCD player sehingga menggunakan kaset tape rol manual dan kepingan kaset $V C D$.

Program siaran yang disiarakan oleh RRI beragam dan mengacu kepada kebutuhan masyarakat umum Madiun. Program siaran meliputi siaran berita atau informasi (news and information), siaran pendidikan (educational program), siaran kebudayaan (cultural program), siaran hiburan (Entertaiment program) dan siaran iklan ataupun penunjang (advertisement micellany). Selain program siaran, ada pula program 
jasa siaran yang dibagi menjadi siaran iklan komersial, iklan layanan masyarakat dan berita kehilangan ataupun siaran informasi yang sifatnya pengumuman yang harus diketahui oleh masyarakat.

Program siaran RRI selalu berkoordinasi dengan RRI pusat, sehingga sebulan sekali RRI cabang Madiun harus mengirimkan laporan ke pusat. Jam siaran RRI pada awal reformasi masih 24 jam, tetapi pada tahun 2002 adanya perubahan jam siaran menjadi 20 jam yang dikarenakan untuk penghematan energi. RRI belum bisa leluasa menyiarkan program siarannya secara bebas dikarenakan harus me-relay siaran dari RRI pusat. Program siaran yang menjadi primadona pada waktu itu adalah siaran wayang, campur sari dan ludruk, yang mana masyarakat menunggu.

RRI memiliki dua gelombang siaran yaitu Programa 1 (Pro1) dan Programa 2 (Pro2). Adanya kewajiban relay menjadikan RRI membagi siaran menjadi dua gelombang. Pro1 disiarkan selama 24 jam yang berisi tentang berita lokal Karisidenan Madiun yang menyangkut tentang berita daerah, kebudayaan, musik dan hiburan. Pro2 adalah kewajiban relay RRI cabang madiun yang menyiarkan siaran acara dari RRI pusat dan disiarkan selama 24 jam. Radio Gabriel yang sering dikenal dengan sebutan Ge FM berdiri sejak tahun 1966, yang awalnya hanyalah sebuah radio komunitas gereja Kristen Khatolik yang hanya mengudra pada saat-saat tetu saja. Radio Ge FM pada mulanya adalah radio komunitas amatir, namun karena eksistensinya mengudara dan dengan dibentuknya Badan Pembida Radio Siaran Swasta Nasional di Jawa Timur radio Ge FM ahkirnya berubah menjadi Perusahaan Persero Terbatas.

Semenjak berubah menjadi radio swasta dengan jasa penyiaran radio Ge FM berkembang dengan pesat. Studio siaran radio Ge FM berpindah tiga kali karena pada saat itu memang belum mempunyai lahan sendiri dan masih menyewa. Pertama kali berdiri studio siaran Ge FM berada di Jl. A.Yani No.10 dan pada tahun 1969 studio siaran radio GeFM berpindah di Jl. Cokro Aminoto No.111 Hingga pada akhirnya radio Ge FM membangun studi siarannya di $\mathrm{Jl}$. Pasanggrahan V Taman Madiun pada tahun 1982 sampai saat ini.

Radio Ge FM tergolong kedalam jenis radio Commercial Station radio yaitu radio milik pribadi yang digunakan untuk mencari keuntungan komersial. Teknologi penyiaran radio Ge FM pada awal berdirinya sangatlah sederhana dalam penyiarannya masih manual atau analog menggunakan tape recorder dan piringan hitam. Antenna yang dimiliki oleh rado Ge FM juga masih terbuta dari 
bambu. Program siaran radio Ge FM pada tahun awal bediri masih menyiarkan siaran rohani bagi penganut agama Kristen katholik. Namun tidak hanya itu radio Ge FM juga menyiarkan acara hiburan yang disiarkan oleh pemerintah seperti wayang kulit, campursari dan berita kenegaraan.

Gelombang yang dimiliki oleh radio Ge FM pada awalnya belum menggunakan frekfensi modulasi (FM) namun masih mengunakan audio modulasi (AM). Berkembangnya radio Ge FM dan berubah status menjadi radio swasta berubah juga gelombang yang dimiliki oleh radio Ge FM. Tidak lagi berada pada gelombang audio modulasi (AM) namun menjadi frekfensi modulasi (FM) dengan gelombang siar 95,2 Mhz.

Duta Cakrawala Serasi FM atau yang dikenal oleh masyarakat Madiun dengan sebutan radio DCS FM. Radio ini tumbuh sejak tahun 1991 dan resmi mengudara tahun 1992 dengan mengantongi izin resmi dari Direktorat Jendral Departemen Priwisata, Pos dan Telekomunikasi Republik Indonesia. Adanya izin resmi yang dimiliki DCS FM membuat radio ini dapat diterima oleh masyarakat dan menjadi radio baru yang menjadi favorit yang bersaing dengan RRI cabang Madiun dan Ge FM.

Sejak awal berdiri DCS FM sama dengan Ge FM yaitu radio swasta yang telah memiliki izin resmi. DCS tergolong kedalam jenis radio Commercial Station radio yaitu radio milik pribadi yang digunakan untuk mencari keuntungan komersial. Berkembangnya radio DCS FM dipengaruhi oleh banyaknya jumlah pengiklan yang menggunakan jasa iklan siaran kepada radio DCS FM. Awal berdiri sampai tahun 2000 struktur pengurusan dan jumlah kariawan tidak mengalami perubahan.

Pasca reformasi dan adanya perlindungan hukum terhadap pers cetak maupun pers elektronik DCS FM mulai berkembang dan berorientasi didalam dunia huburan. Sasaran pendengar radio DCS FM 50\% adalah remaja, 25\% dewasa, 15\% lansia dan 10\% anak-anak. Awal berdirinya radio DCS FM mempunyai pemancar yang dipakai masih menggunakan antena biasa sehingga jangkauannya belum luas, hanya meliputi sekitar daerah madiun saja. Teknoligi penyiaran yang digunakan pada saat itu juga masih manual atau analog yang sederhana.

Pemutaran musik dilakukan dengan menggunakan $V C D$ atau bahkan tape juga piringan hitam. Adanya pemasukan iklan dan manajemen yang baik pada tahun 2000, pimpinan radio DCS FM memutuskan untuk membangun studio siaran yang lebih layak. Menimbang bahwa studio siaran radio DCS FM yang pada saat itu berada di Jl. Ahmat Yani masih menyewa dan 
letaknya kurang luas sehingga sulit untuk berkembang. Pada tahun 2003 radio DCS FM sedah memiliki aset berupa bangunan sendiri yang lebih strategis dan luas yaitu di Jl. Kelapa Manis No.38. Adanya perpindahan tempat baru radio DCS FM juga mengurusi perizinan penyiaran di pemerintah pusat. Perubahan peraturan perundangundangan yang dikarenakan banyak radio amatir yang bermunculan dan berkembang membuat frekuensi radio DCS FM berubah dari 101.06 FM menjadi 100.50 FM hingga saat ini.

Program siaran radio DCS FM mengacu pada sasaran pendengar yaitu remaja, sehingga radio DCS FM terkenal dengan selogan the line of music. Program siaran yang mendominasi adalah musik-musik pop remaja baik dari musik pop Indonesia dan musik pop manca negara. Pada era globalisasi tahun 2000 radio swasta seluruh Indonesia termasuk radio DCS FM mengalami penurunan jumlah pendengar yang dikerenakan maraknya dan berkembang internet dimasyarakat.

Adanya penurunan pendengar, radio DCS FM menyikapinya dengan cara membagi program siaran msecara merata. Tidak hanya acara musik yang diunggulkan namun adanya acara yang lebih berfariatif, selain itu untuk melakukan penghematan biaya radio DCS FM memangkas jam siaran dari 24jam menjadi 20 jam yang dimulai pada jam 05.00 sampai jam 24.00.

Radio Madya Citra Suara FM adalah radio sawasta yang tumbuh dan berkembang di Madiun, lahir pada 1 Oktober 2002. Pada awal berdiri sudah memiliki perijinan dan hak siaran dari pemerintah. Madya FM adalah sapaan yang diberikan oleh masyarakat Madiun yang setia mendengarkan Radio Madya Citra Suara FM. Madya FM memperkenalkan diri sebagai media komunikasi, hiburan dan promosi, serta memposisikan sebagai radio daerah yang membidik target pendengar umum (general), kental dengan sifat lokalitas dan kedekatan dengan pendengar atau konsumen.

Enam bulan pertama Madya FM melakukan siaran 20 jam penuh dengan memutar lagu pop, dangdut, campur sari dan mancanegara. Tujuan pemutaran lagu ini dikarenakan sebagai promosi dan belum adanya rekrutmen karyawan dan manajemen radio Madya FM.

Pada awal bulan Mei 2013, Yuswanto (pendiri Radio Madya FM) sudah membangun manajemen perusahaan dan melakukan rekrutmen karyawan. Program yang disiarkan masih didominasi oleh musik-musik yang populer dikalangan masyarakat. Madya FM dari awal berdiri sudah menggunakan system komputerisasi, sehingga tidak menggunakan peralatan 
analog. Dalam setahun pertama Madya FM masih dalam pembenahan sistem perusahan, mencari sumber anggaran dan menata program siaran, sehingga Madya FM bisa menjalakan Visi dari perusahaan, yaitu menjadi media sarana hiburan, promosi dan sumber informasi masyarakat Madiun.

\section{B. Periode Kedua Perkembangan Radio} Sebagai Pers Elektronik Tahun 20042013

Keluaran dari organisasi radio adalah siaran yang mana setiap mata acara siaran direncanakan, diproduksi dan disajikan kepada pendengar dengan isi pesan yang bersifat informatif, edukatif dan komunikatif. Seiring berjalannya waktu radio tidak akan pernah lepas dari pengaruh globalisasi yang senantiasa berubah dalam jangka pendek maupun jaka panjang. Masyarakat adalah faktor utama dalam perkembangan radio serta indeks yang menentukan perkembangan stasiun radio. Oleh karena itu, semua stasiun radio dituntut agar dapat mengikuti arus globalisasi.

RRI cabang Madiun setelah merubah status menjadi LPP (Lembaga Penyiaran Publik) tahun 2005, dituntut lebih kreatif dalam penyajian informasi, berita, hiburan dan budaya tanpa meninggalkan relay dari RRI pusat. Inovasi baru yang dibuat oleh RRI cabang Madiun yaitu dengan pengaturan program gelombang siaran. Program gelombang siaran RRI cabang Madiun di bagi menjadi tiga gelombang, yang tadinya hanya Pro1 dan Pro2 kini bertamabah menjadi Pro3. Bertambahnya gelombang siaran juga berpengaruh dalam penyusunan acara dalam setiap gelombang siaran.

Kini Pro1 menyiarkan acara yang berkaitan dengan pusat pemberdayaan masyarakat Madiun yang meliputi informasi yang berkaitan dengan pemerintahan, ekonomi, pendidikan, kesehatan dan seni budaya Madiun. Pro2 merupakan gelombang siaran baru yang menyiarkan pusat kreatifitas anak muda yang berkaitan dengan musik, wawasan umum dan informasi pendidikan. Pro3 adalah kewajiban relay RRI cabang Madiun yang menyiarkan RRI pusat yaitu tentang berita nasional. Jam siar Pro1 dan Pro2 hanya 20 jam yang dimulai dari jam 05.00 hingga jam 24.00 hal ini dikarenakan untuk penghematan energi, sedangkan Pro3 diasiarkan selama 24 jam.

Dengan berkembangnya gelombang siaran Pro1, Pro2 dan Pro3 maka acara siaran menjadi lebih fariatif dan inovatif. Masyarakat dapat memilih acara mana yang menjadi favorit dan tidak hanya mendengarkan relay dari pusat, namun dapat mendengarkan 
berita tentang wilayah karisidenan Madiun. Adapun acara unggulan dari Pro1 adalah :

1. Mutiara Pagi : Kajian Islam aktual oleh Nara Sumber terpercaya.

2. Siraman Rohani Islam : Sajian Dialog Interaktif Islami, dg mengangkat masalah aktual, Nara Sumber KH. M Sutoyo, M Ag (Ketua MUI) Kota Madiun.

3. Panorama Pagi : Sajian Dialog Interkatif dengan pendengar, membahas topik terhangat dan aktual.

4. Dialog Realita : Dialog Interaktif, membahas topik aktual masalah sosial, Pendidikan, Budaya, Hukum, Ekonomi bisnis, Politik dan sejenisnya, Menghadirkan Nara Sumber Visioner yang mampu memberikan solusi.

5. Camilan : Pelestarian Budaya Jawa melalui PIP.

6. Lembaran Wanita : Program Khusus untuk Kaum Wanita, Kisah sukses perempuan untuk semua tingkatan.

7. Senandung Malam : Sajian tembang kenangan secara Live di Studio Wahana Wara RRI Madiun diiringi musik Elektone, mengajak pendengar mengenang masa lalu, sambil bernostalgia.

8. Zona Pendidikan : Sajian Pembinaan Bahasa Indonesia,
English Program, Apresiasi Seni dan Budaya, Lestari Alamku, Dialog Kesehatan dengan mengundang pakar di bidang-Nya.

9. Ragam Musik \& Kesenian Tradisional : Sajian Musik Tradisional dan Budaya lokal diselingi obrolan santai.

Sedangkan acar unggulan dari Pro2 adalah:

1. Permisi/Just Music (Pro 2 Musik Index): Full pemutaran Lagu yg telah disiapkan oleh MD, Info seputar musik update.

2. Pro 2 Kreatif : Sajian Informasi yg berkenaan dengan gaya hidup remaja, Topik dan Tema berbeda, diselingi Musik, Spot, Jinggle.

3. Memory Box : Memutar lagu-lagu memori dari 1995 - 2005 tanpa request

4. Hits \& Play : Request lagu / Single Indonesia terbaru Via SMS/Telp.

5. Pro 2 Top Indo : 20 lagu Hits Indonesa via Polling SMS

6. Pro 2 Populer : Sajian Informasi Artis/Musisi, Pendidikan, Inspirasi Remaja dan profil Dunia Musik.

Memasuki tahun 2005 RRI mulai meninggalkan sistem analog dan sistem penyiaran yang ada di RRI berubah menjadi sistem komputerisasi, hal disebapkan karena adanya pengaruh globalisasi. Perkembangan RRI juga bisa dilihat dari didirikannya 
pemancar yang ada di daerah Pacitan, Magetan dan Ngawi sehingga siaran dapat didengarkan di wilayah karisidenan Madiun dengan jelas.

Pada tahun 2010 karena adanya tuntutan dari RRI pusat, RRI cabang Madiun meluncurkan website www.rrimadiun.net yang digunakan untuk melakukan siaran audio streaming. Tahun 2011 RRI cabang Madiun sudah terkoneksi dengan RRI pusat didalam webside www.rri.co.id sehingga RRI cabang Madiun tersambung dengan seluruh RRI yang ada di Indonesia.

Pada tahun 2012 RRI meluncurkan satelit dan membuat aplikai software yang dipergunakan di smartphone androit yang bertujuan memudahkan pendengar dalam mendengarkan siaran. RRI cabang Madiun adalah satu-satunya yang mempunyai studio digital dan peralatan pemancar digital tetapi belum bisa pergunakan karena masyarakat belum akrap dengan radio digital.

Perkembangan Teknologi penyiaran tidak saja dialami oleh RRI tetapi juga dialami oleh radi swasta atau radio amatir yang ada di Madiun seperti Gabriel atau Ge FM, radio DCS FM dan radio Madya FM. Radio-radio tersebut juga mulai meninggalkan system analog dan berubah menggunakan sistem komputerisasi.
Memutar musik atau lagu-lagu tidak lagi menggunakan tape, piringan hitam dan vcd melainkan menggunakan komputer, hal ini dirasa lebih praktis, cepat, hemat listrik dan mudah dalam melakukan siaran radio.

Radio-radio tersebut tidak hanya menggunakan komperisasi melainkan untuk mengikitu arus globalisasi mereka menggunakan system radio streaming dimana radio DCS dan Ge Fm mempermudah pendengarnya untuk mendengarkan siaran baik yang sedang onair maupun offair. Radio Madya tidak menggunakan sistem streaming dikarenakan masih minimnya minat pendengar radio Madya dalam radio streaming.

Program acara yang ada di radio Ge FM juga mengalami perkembangan secara bertahap. Radio ini memiliki ciri khas dalam setiap program acara yang disiarkan yaitu selalu menyiarkan lagulagu kenagan dalam setiap pergantian program acara. Ge FM tidak menargetkan memutar lagu-lagu terkini, tetapi pemuratan lagu-lagu kenangan adalah yang paling utama. Program acara Ge FM selain memutarkan tembang kenagan juga mengutamakan kesenian lokal, terbukti dengan penyiaran kesenian wayang kulit sebagai program acara unggulan dari radio Ge FM. Pengelolaan dan manajemen yang baik membuat Ge FM 
masih tetap eksis dalam industri pelayanan jasa siaran diwilayah karisidenan Madiun.

Radio DCS FM juga mengalami perkembangan, yaitu dalam segi penatan program siaran. DCS FM memiliki sasaran pendengar remaja pada umumnya, sehingga dalam penatan program acara menekankan acara-acara yang bersifat hiburan. Musik atau lagu-lagu terkini adalah program unggulan yang selalu diputar dan mengalami pembaruan sesuai dengan perkembangan musik Indonesia maupun musuk mancanegara.

Radio DCS FM agar dapat mempertahankan eksistensinya dengan menduplikasi acara-acar yang ada di tv yang sekiranya menarik minat pendengar seperti acara Conan ( Comic On Air-an) yaitu program siaran ajang menghadirkan lelucon stnd up comedy. Program unggulan on air yang di siarkan oleh radio DCS FM diantaranya adalah :

1. MoTeGi (Morning Teman Pagi), merupakan ajang request dipagi hari untuk memberikan semangat dalam beraktifitas dipagi hari. Lagu yang diputar 70\% lagu middle-up beat, $30 \%$ lagu slow berdasarkan request.

2. Pro Manca, ajang memutar lagu-lagu manca top 40 (full request).

3. Pro Indo, ajang memutar lagu-lagu Indo top 40 (full request).
4. Gita Nuansa, ajang request dan kirim salam lagu slow dan middle manca dan persada 90 -an terbaru atau top 40 (full request).

5. Ketawa-ketiwi, sisipan humor di semua ajang, isinya adalah humor segar untuk membuat pendengar tersenyum dahkan tertawa setelah mendengarnya.

6. DCS TOP 40, ajang Chart atau tangga lagu yang menghadirkan 40 lagulagu manca terbaru.

7. ROS (Rock On Sunday), ajang request dan kirim salam lagu-lagu rock manca dan persada.

Radio Madya adalah radio muda dibandingkan denga radio Ge FM dan juga radio DCS FM. Radio Madya lahir diera globalisasi sehingga dalam sistem penyiaran menggunakan sistem komputerisasi. Selama tahun 2002 sampai tahun 2012 adalah masa perjuangan radio Madya FM dimana pada tahun awal berdiri Madya FM belum memiliki studionya sendiri. Tahun 2013 Madya FM sudah memiliki studionya sendiri lebih luas dan strategis.

Program acara siaran radio Madya FM sejak awal berdiri tidak begitu banyak mengalami perkembangan. Program acara siaran radio Madya FM jika dibandingkan dengan radio-radio lain sangatlah berbeda, yaitu radio Madya FM tidak memiliki acara sebanyak dan sepadat radio-radio lain. Cirri khas 
dari radio Madya FM yaitu pergantian program acara adalah tiga jam sekali, menurut radio Madya FM terlalu banya program acara tidak efektif. Pergantian program acara selama tiga jam sekali disebapkan agar pendengar radio Madya FM dapat menghafal program acara radio Madya FM. Program acara radio Madya FM walaupun tidak sebanyak radio-radio lain namun tetap memiliku acara-acara unggulan yaitu :

1. Sapa Madya, sajian rohani islam yang terkemas dalam voice of islam tanpa penyiar, dengan harapan memberi nuansa islami.

2. Dara top Madya, lantunan lagu dangdut baru dengan selingan info artis dan gosip selebritis dangdut.

3. Ever green Madya, mengajak pendengar Madya FM untuk bernostalgia, disertai dengan tipstips menarik.

4. Campursari top Madya, lagu campursari yang masih dirindukan kehadirannya oleh pencinta Madya.

5. GSM, lantunan lagu-lagu dangdut konfensional yang kental nuansa dangdutnya, mengajak pencinta Madya bergoyang senggol.

6. Kafe Musik Madya, menampilkan lagu-lagu dalam kemasan lagu terbaru, yaitu lagu pop indo dan lagu pop manca.

7. Memorabilia Madya, ungkapan selamat malam untuk pencinta
Madya dengan diiringi lagu-lagu kenangan.

\section{Penutup}

\section{Simpulan}

Radio adalah salah satu pers elektronik yang berfungsi sebagai penyebar informasi dan hiburan pada khalayak. Perkembangan radio sebagai pers elektronik di Kota Madiun pasca reformasi mengalami perkembangan yang cukup pesat. Letak dipersimpangan kota besar dan adanya kebebasan maupun perlindungan pers, membuat radio mulai berkembang dan menjamur sebagai sarana komunikasi audio yang fleksibel yang menawarkan banyak kemudahan. Berdirinya RRI cabang Madiun menjadi cikal bakal tumbuhnya radio swasta lainnya seperti Ge FM, DCS FM, Madya FM dan radio lainya.

Perubahan dari sistem penyiaran dari analog menjadi sistem komputerisasi adalah indikasi dari perkembangan radio yang ada di Madiun. Pengaruh globalisasi dan efisiensi yang adalah faktor penyebab agar radio tetap eksis dan mengudara. Pengembangan daya kreatifitas dalam penyajian siaran adalah tuntutan dari setiap stasion siaran radio. Penduplikasian acara televisi yang dibungkus dalam format audio. Konvergensi dengan media internet, televisi dan surat kabar adalah solusi untuk menyikapi persaingan yang terjadi. Penerapan radio streaming merupakan pelebaran siaran melalui media internet yang mana sudah dimiliki setiap radio. 


\section{Saran}

\section{Bagi Masyarakat Kota Madiun}

Menjamurnya stasion siaran radio yang ada di Kota Madiun membantu masyarakat dalam memperoleh hiburan dan informasi dari berbagai bidang baik pendidikan, ekonomi, kesehatan, politik maupun sosial budaya. Hendaknya masyarakat dapat memanfaatkan radio sebagai wadah untuk menyampaikan aspirasi, kritik dan saran untuk pembangunan Madiun dan masukan buat stasion radio itu sendiri dalam pembenahan susunan siaran.

\section{Bagi RRI Madiun, Radio Ge FM, Radio} DCS FM dan Radio Madya FM

Perusaan siaran radio agar dapat eksis dan berkembang dalam menjalankan tugas sebagai penyebar informasi dan hiburan yang berada di wilayah Kota Madiun. Penyajian siaran agar dapat dibungkus se-kreatif mungkin dan bersifat edukatif agar dapat meningkatkan minat pendengar. Perusahaan radio juga dapat dijadikan sebagai fasilitator penyampaian aspirasi masyarakat, bertahan dalam mengawal jalannya pemerintahan, menjalankan fungsinya sebagai fungsi kontrol sosial, wadah informasi, sarana publikasi dan sarana hiburan masyarakat.

\section{Daftar Pustaka}

$$
\begin{array}{ccc}
\text { Antonius Darmanto. } 1998 . & \text { Teknik } \\
\text { Penulisan Naskah } & \text { Radio. } \\
\text { Yogyakarta: Universitas Atma Jaya }
\end{array}
$$

Arief Furchan. 1992. Pengantar Metode Penelitian Kualitatif. Surabaya: Usaha Nasional

Asep Samsul M. 2009. Dasar-Dasar Siaran Radio: Basic Announcing. Bandung: Nuansa

Atie Rachmiatie.2007. Radio Komunitas Eskalasi Demokratisasi Komunikasi. Bandung: Simbiosa Rekatama Media

Badan Pusat Statistik. 2011. Kota Madiun Dalam Angka 2011. Madiun: CV Aneka Surya

Basri MS. 2006. Metode Penelitian Sejarah. Jakarta: Restu Agung

Emy Susanti. 2008. Metode Penelitian Sosial: Berbagai Alternatif Pendekatan. Dalam Bagong Suyanto dan Sutinah (eds). Jakarta: Kencana

Emzir. 2011. Metodologi Penelitian Kualitatif Analisis Data. Jakarta Utara: PT. Radja Grafindo Persada

H.B Sutopo. 2006. Metodologi Penelitian Kualitatif. Surakarta: Universitas Sebelas Maret.

Harley Prayudha. 2006. Radio: Penyiar It's Not Just a Talk. Malang: Bayumedia Publishing

Hilman Adil. dkk. 2002. Beberapa Segi Sejarah Pers di Indonesia. Jakarta: PT Kompas Media Nusantara

Husaini Usman dan Purnomo Setiady Akbar. 2004. Metodologi Penelitian Sosial. Jakarta: PT. Bumi Aksara

Joko Subagyo. 2004. Metode Penelitian. Jakarta: PT.Rineka Cipta

Lus Y.Triartanto. 2010. Broadcasting Radio Panduan dan Praktik. Yogyakarta: Pustaka Book Publisher 
Masduki. 2004. Menjadi Broadcaster Profesional.Yogyakarta: Pustaka Populer LKiS

Masduki. 2006. Jurnalistik Radio. Yogyakarta: LKiS

Nasution. 2004. Metode Research. Jakarta: PT Bumi Aksara

Onong Uchjana E. 2009. Ilmu Komunikasi Teori dan Praktik. Bandung: PT Remaja Rosdakarya

Rianto Adi. 2005. Metodologi Penelitian Sosial dan Hukum. Jakarta: Granit

Santi Indra A. 2008. Jurnalisme Radio Teori dan Praktik. Bandung: Simbiosa Rekatama Media

Sugiyono. 2007. Metode Penelitian Kuantitatif, Kualitatif dan $R \& D$. Bandung: CV ALFABETA

Sugiyono. 2012. Memahami Penelitian Kualitatif. Bandung: AIFBETA CV
Suharsimi Arikunto. 2010. Prosedur Penelitian. Jakarta : PT Rinekacipta

Supardi Haliman. 2007. Regulasi Sistem Penyiaran di Indonesia. Yogyakarta: Pararaton

Syahrul. dkk. 2004. Hubungan Media yang Efektif. Jakarta: Erlangga

Totok Djuroto. 2002. Manajemen Penerbitan Pers. Badung: PT Remaja Rosdakarya

William L.Rivers. dkk. 2008. Media Masa dan Masyarakat Moderen. Jakarta: Kencana 